\title{
Amygdalin protects apoptosis of retinal ganglionic cells in glaucoma rats by regulating the expressions of anti- and pro-apoptotic proteins
}

\author{
Xiaoli Zeng ${ }^{1,2}$, Hongbin Lv ${ }^{1 *}$, Xuewen Huang ${ }^{2}$ \\ ${ }^{1}$ Department of Ophthalmology, The Affiliated Hospital of Southwest Medical University, Sichuan, Luzhou 646000, ${ }^{2}$ Department \\ of Ophthalmology, Nanchong Central Hospital, Sichuan, Nanchong 637000, China
}

*For correspondence: Email: BertaJoycecid@yahoo.com; Tel: 0086-0830-3165200

Sent for review: 24 June 2019

Revised accepted: 18 May 2020

\begin{abstract}
Purpose: To evaluate the protective effect of amygdalin against glaucoma.

Methods: Glaucoma was induced in rats via ischemia/reperfusion. The rats were treated with amygdalin (1 mg/kg) intraperitoneally (ip) for 5 weeks. Intra-ocular pressure (IOP), viability of retinal ganglion cell (RGCS) and histopathological changes in the retinal tissue of the glaucoma rats were determined. The expression levels of inflammatory cytokines and expressions of apoptotic factors were assessed in retinal tissues of all groups.

Results: Intra-ocular pressure was reduced in amygdalin-treated group, when compared with the glaucoma group $(p<0.05)$. Moreover, the viability and thickness of RGCs in the amygdalin-treated group were enhanced, relative to untreated glaucoma rats. There was decrease in retinal cytokine levels in amygdalin-treated group, when compared with untreated glaucoma rats. Amygdalin treatment ameliorated altered expressions of apoptosis proteins in the retinal tissue of ischemia/reperfusioninduced glaucoma rats.

Conclusion: Amygdalin has a protective effect against ischemia/reperfusion-induced glaucoma in rats. Thus, it has a potential for use in the clinical management of glaucoma.
\end{abstract}

Keywords: Glaucoma, Amygdalin, Cytokines, Ischemia/reperfusion, Apoptosis

\begin{abstract}
This is an Open Access article that uses a fund-ing model which does not charge readers or their institutions for access and distributed under the terms of the Creative Commons Attribution License (http://creativecommons.org/licenses/by/4.0) and the Budapest Open Access Initiative (http://www.budapestopenaccessinitiative.org/read), which permit unrestricted use, distribution, and reproduction in any medium, provided the original work is properly credited.

Tropical Journal of Pharmaceutical Research is indexed by Science Citation Index (SciSearch), Scopus, International Pharmaceutical Abstract, Chemical Abstracts, Embase, Index Copernicus, EBSCO, African Index Medicus, JournalSeek, Journal Citation Reports/Science Edition, Directory of Open Access Journals (DOAJ), African Journal Online, Bioline International, Open-J-Gate and Pharmacy Abstracts
\end{abstract}

\section{INTRODUCTION}

Glaucoma is a severe ocular disorder which results in irreversible loss of vision due to degeneration of retinal ganglion cells [1]. A report has revealed that the number of glaucoma patients may increase to about 112 million in 2040 [2]. Intraocular pressure (IOP) is elevated in glaucoma patients, leading to apoptosis of retinal ganglion cells [3]. Studies have revealed that ischemia/reperfusion in retinal tissue contributes to changes in IOP. The pathogenesis of apoptosis of retinal ganglion cells involves several factors, including neuro-inflammation and oxidative stress [4]. Conventional drugs available for the treatment of glaucoma are not able to prevent damage to retinal ganglion cells. Thus, there is need for development of newer and more effective drugs for the treatment of glaucoma. 
Over the years, alternative medicine has shown beneficial effect in the management of several disorders, amongst which is glaucoma. Amygdalin is an aromatic cyanogenic glycoside present in different plants such as plum, cherry, peach and apricot [5]. The potential of amygdalin as an anti-histaminic, anti-tussive, anti-ulcer and anti-inflammatory agent has been demonstrated in many studies [6-9]. Moreover, amygdalin protects the lung from hypoxia-induced injury, and it exerts beneficial effect against atherosclerosis [10, 11]. In addition, amygdalin shows protective effect against several types of cancers such as rectal, colon, lung and prostate cancers, and it mitigates cancer-induced pain [12]. The present investigation was carried out to determine the effect of amygdalin on ischemia/reperfusion-induced glaucoma in rats.

\section{EXPERIMENTAL}

\section{Animals}

Sprague-Dawley rats (200-230 g) of either sex were kept under 12-h light/dark cycle under controlled conditions of $60 \pm 5 \%$ relative humidity and $24 \pm 3{ }^{\circ} \mathrm{C}$. Experiments on animals performed in the report as per the directions given in Association for the Assessment and Accreditation of Laboratory Animal Care International guideline [13] and approved by the Institutional Animal Ethical Committee of The Affiliated Hospital of Southwest Medical University, China (no. IAEC/AH-SMU/2017/12).

\section{Animal grouping and treatment}

Intraocular hypertension was produced by ischemia/reperfusion as per studies reported previously [14]. The rats were anesthetized using pentobarbitone $(100 \mathrm{mg} / \mathrm{kg}$, ip). Topical application $0.5 \%$ alcaine eye drops was used for anesthetizing the corneas. Tropicamide (1\%) was used to dilate the pupils. Thereafter, cannulation was done using 30-gauge needle to the right eye. This procedure was performed by maintaining an IOP of $70 \mathrm{mmHg}$ for $1 \mathrm{~h}$. Later withdrawing needle was used to normalize the IOP. The rats were divided into three different groups: normal group, glaucoma group which received saline solution, and amygdalin-treated group which was given amygdalin at a dose of 1 $\mathrm{mg} / \mathrm{kg}$, ip for 5weeks. Intraocular pressure (IOP) was estimated after cauterization of vein using Tonopen XL tonometer.

\section{RGC labeling and quantitation of survival}

The rats were placed on a stereotactic apparatus after anesthetizing them with pentobarbital (100 $\mathrm{mg} / \mathrm{kg}$, ip). Povidone-iodine (PVP-I) was used to clean the exposed skull. Bilateral holes were drilled in the superior colliculi, into which $1 \mu \mathrm{L}$ of flurogold (FG; 4\%) was injected. Then, tobramycin was applied on the dissected-out scalp.

\section{Histopathological examination}

Histopathological changes were determined as per previously reported studies. Davidson's solution containing acetic acid (12.5\%), paraformaldehyde (9.3\%) and ethanol (37.5\%) was used to fix the enucleated eyes at room temperature for $24 \mathrm{~h}$. The isolated eyes were seeded in molten paraffin after removing the lenses. Retinal sections of 5-mm thickness were sliced using a microtome and subjected to hematoxylin and eosin (H\&E) staining. The stained slices were examined under a light microscope and photographed, followed by estimation of counts of retinal ganglion cell layer (GCL).

\section{Determination of cytokines}

Cytokines level was observed in the retinal tissue of $I / R$ induced glaucoma rat model by using ELISA as per the guidelines suggested by the manufacturer of kits.

\section{Determination of mRNA expression of apoptosis factors}

In the retinal tissue, mRNA expression of factors contributes in the apoptosis were determined by qRT-PCR. Trizol Reagent was used to isolate the RNA from the separated gingival tissues and further Revert Aid First Strand cDNA Synthesis Kit was used to reversely transcribed the isolated RNA to cDNA. Quantitative SYBR Green PCR assay was used to estimate the expressions of gene by mixing the RT 2 SYBR Green Master with the used primers. All the samples were maintained at the series of programmed temperature and relative standard curve was used to estimate the level of mRNA expressions.

\section{Western blot assay}

NP40 protein lysis buffer was used to extract the protein from the isolated retinal tissues and concentration of protein was estimated by DC protein assay. Isolation of protein was done by using sodium dodecyl sulfate (SDS)-polyacrylamide gel electrophoresis (10\%) and further filter the collected protein with membrane. Further membrane was treated with blocking agent to block the activity of membrane and separated membrane was incubated at $4{ }^{\circ} \mathrm{C}$ with primary 
antibodies for Akt, NF-kB, Bcl-2, Bax, caspase-3 and $\beta$-actin for the period of overnight. Later secondary antibodies was used to further incubate the membrane for $60 \mathrm{~min}$ at room temperature. ImageLab software was used to determine the density of the blot, which was enhanced by chemiluminescence.

\section{Statistical analysis}

Result of the study expressed as mean \pm SEM ( $n$ $=8$ ). One-way ANOVA was used for statistical analysis with post hoc test (Graph pad Prism 6.1, CA, USA). Statistical significance was set at $p<$ 0.05 .

\section{RESULTS}

\section{Effect of amygdalin IOP}

The effect of amygdalin on the IOP in ischemia/reperfusion induced glaucoma rats is shown in Figure 1. The IOP was estimated after each week of amygdalin treatment in ischemia/reperfusion-induced glaucoma rats. There was $(p<0.01)$ increase in IOP in glaucoma group, when compared to the normal group. It was observed that IOP was reduced $(p<0.01)$ in amygdalin group, relative to the glaucoma group.

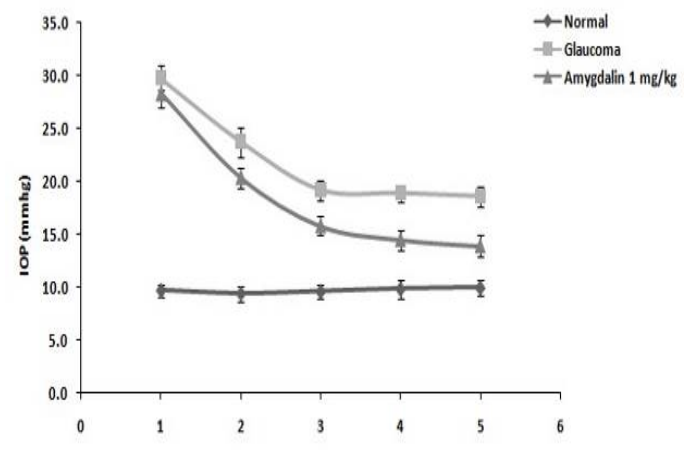

Figure 1: Effect of amygdalin on IOP in ischemia/reperfusion-induced glaucoma rats. Data are mean \pm SEM ( $\mathrm{n}=8$ ); $p<0.01$ vs. normal group; ${ }^{* *} p<$ 0.01 vs. glaucoma group

\section{Effect of amygdalin on survival of RGCs}

The effect of amygdalin on the survival of RGCs in ischemia/reperfusion-induced glaucoma rats is shown using FG-labeled RGCs in Figure 2 A. A weak gold fluorescence was observed in the glaucoma group. However, gold fluorescence in the FG-labeled RGCs was diffuse and bright in the normal and in amygdalin-treated group of ischemia/reperfusion-induced glaucoma rats. Moreover, survival of RGCs was decreased $(p<$ 0.01 ) in glaucoma group on the $2^{\text {nd }}$ and $4^{\text {th }}$ weeks, when compared with the normal group. There were significant increases in the survival of RGCs on $2^{\text {nd }}$ and $4^{\text {th }}$ weeks in amygdalin-treated group of rats, relative to the untreated glaucoma group (Figure 2 B).

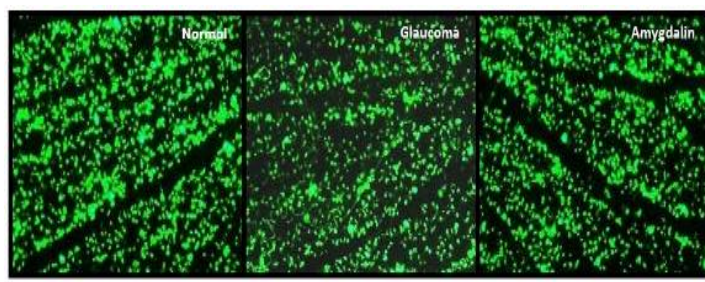

A

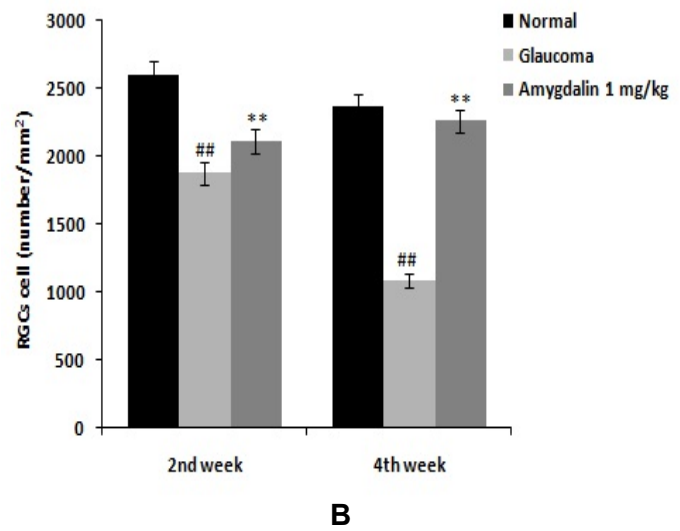

Figure 2: Effect of amygdalin on the survival of RGCs in ischemia/reperfusion-induced glaucoma in rats. A: Images of FG-labeled RGCs in the retinal tissue; B: number of surviving RGCs in the retinal tissue. Data are mean \pm SEM $(n=8) ; p<0.01$ vs. normal group; ${ }^{* *} p<0.01$ vs. glaucoma group

\section{Effect of amygdalin on histopathology of retina}

Histopathological changes in the retinal tissue of ischemia/reperfusion-induced glaucoma in rats using $\mathrm{H} \& \mathrm{E}$ staining are shown in Figure $3 \mathrm{~A} \& \mathrm{~B}$. There were normal structure and normal thickness of retinal tissue, and the number of cells was also high in the retina of normal group. In contrast, transverse sections of retinal tissue in the glaucoma rats showed few cells with reduced layer thickness. However, treatment with amygdalin ameliorated the changes in structure, thickness and number of cells in the retinal tissue of ischemia/reperfusion-induced glaucoma rats (Figure 3A). In glaucoma group, number of cells in the retinal tissue was reduced than in the rats of normal group. Moreover, there was increase in the number of cells in the retinal tissues of amygdalin treatment ameliorates the cells number, relative to the glaucoma group of rats (Figure $3 \mathrm{~B}$ ). 


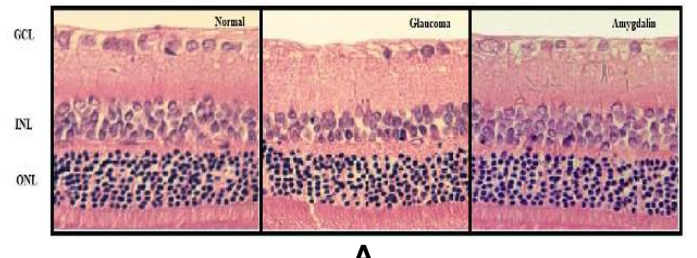

A

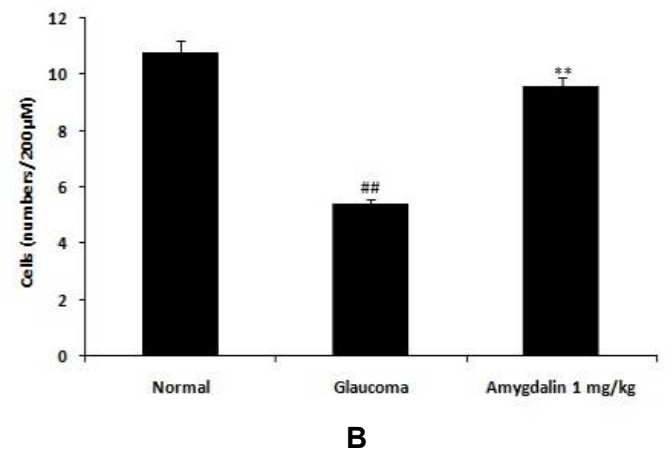

Figure 3: Effect of amygdalin on histopathology of retinal tissue in ischemia/reperfusion-induced glaucoma rats. A: H\&E stained retinal tissue; $B$ : number of cells present in the retina. Data are mean \pm SEM ( $\mathrm{n}=8) ; p<0.01$ vs. normal group; ${ }^{* *} p<0.01$ vs. glaucoma group

\section{Effect of amygdalin on cytokines}

There were decreases in the levels of cytokines in the retinal tissue of glaucoma group, when compared to the normal group of rats. However, treatment with amygdalin enhanced the levels of these cytokines in the retinal tissue, when compared to glaucoma group of rats (Figure 4).

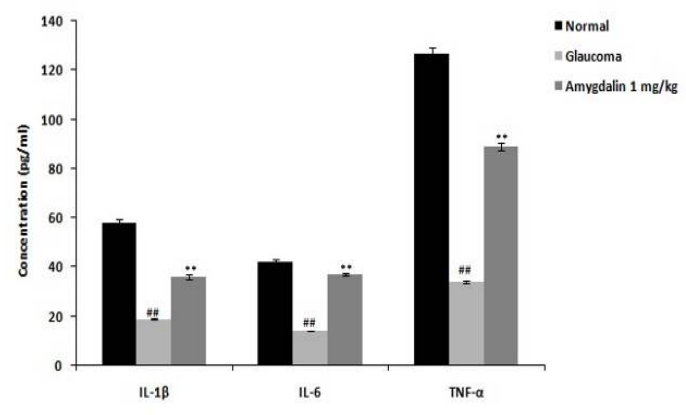

Figure 4: Effect of amygdalin on levels of cytokines in the retinal tissue of ischemia/reperfusion-induced glaucoma rats. Data are mean \pm SEM $(n=8) ; p<0.01$ vs. normal group; ${ }^{* *} p<0.01$ vs. glaucoma group

\section{Amygdalin ameliorates the mRNA expressions of apoptotic factors}

The mRNA expressions of apoptotic factors in the retinal tissue of ischemia/reperfusion-induced glaucoma rats are shown in Figure 5. There were significant increases in the mRNA expressions of caspase-3, caspase-8, Akt and Bax, while the
mRNA expression of Bcl-2 was decreased in the retinal tissue of glaucoma group, when compared with the normal group of rats. However, mRNA expressions of caspase 3 and 8, Akt and Bax were downregulated, while the expression of Bcl2 was increased in the retinal tissue of amygdalin-treated group, when compared with the glaucoma group.

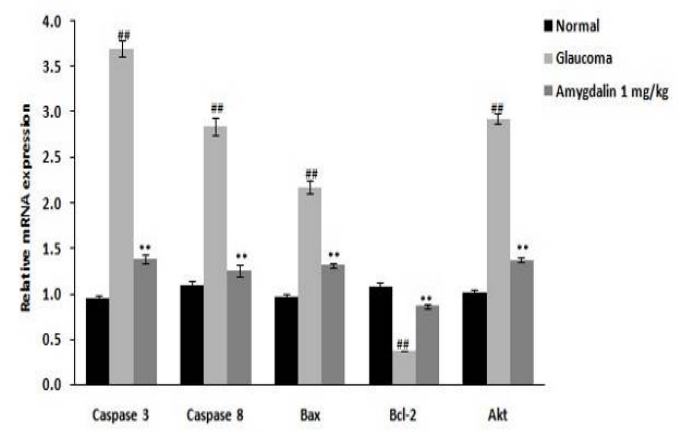

Figure 5: Effect of amygdalin on mRNA expression of apoptotic factors in the retinal tissue of ischemia/reperfusion induced glaucoma rats. Data are mean \pm SEM $(\mathrm{n}=8) ; p<0.01$ vs. normal group; ${ }^{* \star} p<$ 0.01 vs. glaucoma group

\section{Amygdalin ameliorates the expressions of apoptotic and NF-kB protein}

The protein expressions of apoptotic and NF-kB were enhanced, while that of $\mathrm{Bcl}-2$ was reduced in the retinal tissue of glaucoma group, when compared to normal group. However, treatment with amygdalin attenuated the altered protein expressions of caspase-3, Bax, Bcl-2, NF-kB and Akt in the retinal tissue of ischemia/reperfusioninduced glaucoma rats (Figure 6).

\section{DISCUSSION}

Glaucoma is an ocular disease in which IOP and degeneration of retinal ganglion cells are increased, leading to loss of vision [15]. Conventional drugs used for the treatment glaucoma are not focused on the degeneration of retinal ganglion cells. The present study evaluated the protective effect of amygdalin against glaucoma which was induced in rats through ischemia/reperfusion. The rats were then treated with amygdalin at a dose of 1 $\mathrm{mg} / \mathrm{kg}$ for the period of five weeks. The effect of amygdalin was determined via estimation of IOP, survival of RGCs and histopathological changes in the retinal tissue of the glaucoma rats. Moreover, levels of inflammatory cytokines, and protein and mRNA expressions of anti-apoptotic and pro-apoptotic factors were estimated in the retinal tissues. 


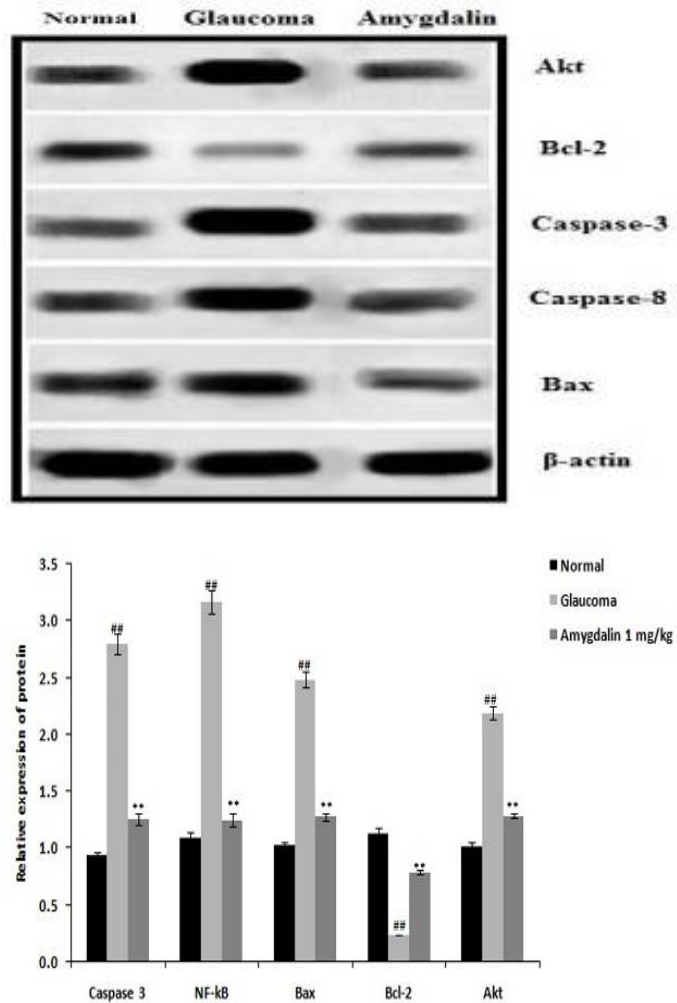

Figure 6: Effect of amygdalin on the protein expressions of apoptotic factors and NF-kB in ischemia/reperfusion-induced glaucoma rats. Data are mean \pm SEM $(\mathrm{n}=8) ; p<0.01$ vs. normal group; ${ }^{* *} p<$ 0.01 vs. glaucoma group

Glaucoma causes irreversible loss of vision. Drugs with antioxidant and antineuroinflammatory properties protect RGCs and thereby reduce IOP. Studies have shown that apoptosis of RGCs contributes to retinal damage in glaucoma due to increase in IOP [16]. The results from the present investigation reveal that treatment with amygdalin reduced IOP in glaucoma rats. The loss of RGCs is attributable to increased IOP in glaucoma. It has been reported that amygdalin protects against neuroinflammation by attenuating altered levels of inflammatory cytokines and NF-kB [17]. Moreover, it has been suggested that inflammatory cytokines are upregulated in glaucoma [18]. In the present study, the amygdalin-treated group had reduced cytokine levels in the retinal tissue, when compared with the glaucoma group of rats.

Several factors are involved in cellular apoptosis, especially pro-apoptotic and anti-apoptotic proteins. Expressions of caspase-3, caspase-8, Bax and Akt (pro apoptotic proteins) are enhanced in apoptosis of cells [19]. The mitochondrial pathway of apoptosis occurs through activation of caspase enzymes [20]. The activation of the caspase cascade contributes to apoptosis of cells. Moreover, upregulation of Bax and downregulation $\mathrm{Bcl}-2$ protein take part in mitochondrial dysfunction and activate cellular apoptosis. The results of the present study suggest that treatment with amygdalin alleviates the altered levels of pro-apoptotic and antiapoptotic factors in the retinal tissues of ischemia/reperfusion-induced glaucoma rats.

\section{CONCLUSION}

The findings of this study demonstrate the protective effect of amygdalin against ischemia/reperfusion-induced glaucoma in rats by regulating the apoptotic factors. These data indicate that amygdalin may be developed for the treatment of glaucoma.

\section{DECLARATIONS}

\section{Acknowledgement}

We would like to thank the management, colleagues and supporting staff of The Affiliated Hospital of Southwest Medical University, China for cooperating and providing facilities for the conduct of this study.

\section{Conflict of interest}

No conflict of interest is associated with this work.

\section{Contribution of authors}

We confirm that the mentioned authors in the manuscript performed the presented work and all the data shown in the manuscript generated the author of it. Xiaoli Zeng performed the methodology and literature review, Hongbin Lv supervised and prepared the manuscript and Xuewen Huang performed histopathology study.

\section{Open Access}

This is an Open Access article that uses a funding model which does not charge readers or their institutions for access and distributed under the terms of the Creative Commons Attribution License (http://creativecommons.org/licenses/by/ 4.0) and the Budapest Open Access Initiative (http://www.budapestopenaccessinitiative.org/rea d), which permit unrestricted use, distribution, and reproduction in any medium, provided the original work is properly credited. 


\section{REFERENCES}

1. Weinreb RN, Aung T, Medeiros FA. The pathophysiology and treatment of glaucoma: a review. JAMA 2014; 311(18): 1901-1911.

2. Quigley HA, Broman AT. The number of people with glaucoma worldwide in 2010 and 2020. Br J Ophthalmol. 2006; 90(3): 262-267.

3. Guo L, Moss SE, Alexander RA, Ali RR, Fitzke FW, Cordeiro MF. Retinal ganglion cell apoptosis in glaucoma is related to intraocular pressure and IOPinduced effects on extracellular matrix. Invest Ophthalmol Vis Sci 2005; 46(1): 175-182.

4. Wan $P$, Su W, Zhang $Y, L i ~ Z$, Deng $C$, Zhuo $Y$. Trimetazidine protects retinal ganglion cells from acute glaucoma via the Nrf2/Ho-1 pathway. Clin Sci (Lond) 2017; 131(18): 2363-2375.

5. Jaswal V, Palanivelu J, C R. Effects of the Gut microbiota on Amygdalin and its use as an anti-cancer therapy: Substantial review on the key components involved in altering dose efficacy and toxicity. Biochem Biophys Rep 2018; 14: 125-132.

6. Do JS, Hwang JK, Seo HJ, Woo WH, Nam SY. Antiasthmatic activity and selective inhibition of type 2 helper $T$ cell response by aqueous extract of semen armeniacae amarum. Immunopharmacol Immunotoxicol 2006; 28: 213-25.

7. Shim SM, Kwon H. Metabolites of amygdalin under simulated human digestive fluids. Int J Food Sci Nutr 2010; 61: 770-779.

8. Hwang HJ, Lee HJ, Kim CJ, Shim I, Hahm DH. Inhibitory effect of amygdalin on lipopolysaccharide-inducible TNF-alpha and IL-1beta mRNA expression and carrageenan-induced rat arthritis. J Microbiol Biotechnol 2008; 18(10): 1641-1647.

9. Paoletti I, De Gregorio V, Baroni A, Tufano MA, Donnarumma G, Perez JJ. Amygdalin analogues inhibit IFN-gamma signalling and reduce the inflammatory response in human epidermal keratinocytes. Inflam 2013; 36: 1316-13126.

10. Chang LW, Zhu HP, Li WB, Liu HC, Zhang QS, Chen HB. Protective effects of amygdalin on hyperoxia-exposed type II alveolar epithelial cells isolated from premature rat lungs in vitro. Zhonghua Er Ke Za Zhi 2005; 43: 118123.
11. Jiagang D, Li C, Wang $H$, Hao E, Du Z, Bao C, Lv J, Wang Y. Amygdalin mediates relieved atherosclerosis in apolipoprotein E deficient mice through the induction of regulatory $T$ cells. Biochem Biophys Res Commun 2011; 411: 523-529.

12. Song $Z, X u X$. Advanced research on anti-tumor effects of amygdalin. J Cancer Res Ther 2014; 10 Suppl 1: 3-7.

13. Guide for the Care and Use of Laboratory Animals: Eighth Edition Committee for the Update of the Guide for the Care and Use of Laboratory Animals; National Research Council. 2010; ISBN: 0-309-15401-4.

14. Varano GP, Parisi V, Adornetto A, Cavaliere F, Amantea $D$, Nucci C, Corasaniti MT, Morrone LA, Bagetta G, Russo R. Post-ischemic treatment with azithromycin protects ganglion cells against retinal ischemia/reperfusion injury in the rat. Mol Vis 2017; 23: 911-921.

15. Davis BM, Crawley L, Pahlitzsch M, Javaid F, Cordeiro MF. Glaucoma: the retina and beyond. Acta Neuropathol 2016; 132(6): 807-826.

16. Rusciano D, Pezzino S, Mutolo MG, Giannotti R, Librando $A$, and Pescosolido N, Neuroprotection in Glaucoma: Old and New Promising Treatments. Advances in Pharmacological Sciences, 2017; 2017: Article ID 4320408.

17. Park BK, Kim YH, Kim YR, Choi JJ, Yang C, Jang IS, Lee MY. Anti-neuroinflammatory and Neuroprotective Effects of Gyejibokryeong-Hwan in LipopolysaccharideStimulated BV2 Microglia, Evidence-Based Complementary and Alternative Medicine, 2019; 2019: Article ID 7585896.

18. Chono I, Miyazaki D, Miyake $H$, Komatsu N, Ehara $F$, Nagase D, Kawamoto $Y$, Shimizu $Y$, Ideta $R$ \& Inoue $Y$. High interleukin-8 level in aqueous humor is associated with poor prognosis in eyes with open angle glaucoma and neovascular glaucoma. Sci Rep 2018; 8(1): 14533.

19. Wang G, Wang JJ, To TS, Zhao HF, Wang J. Role of SIRT1-mediated mitochondrial and Akt pathways in glioblastoma cell death induced by Cotinus coggygria flavonoid nanoliposomes. Int J Nanomed 2015; 10 : 5005-5023.

20. Elmore S. Apoptosis: a review of programmed cell death. Toxicol Pathol 2007; 35(4): 495-516.

21. Hata AN, Engelman JA, Faber AC. The BCL2 Family: Key Mediators of the Apoptotic Response to Targeted Anticancer Therapeutics. Cancer Discov 2015; 5(5): 475-487. 